\author{
Vyacheslav Zhyznevskiy, Volodymyr Gumenetskiy, Olena Matskiv \\ and Olena Shyshchak
}

\title{
EFFECT OF BARIUM SALTS ON PHYSICO-CHEMICAL AN D CATALYTIC PROPERTIES OF Fe-Te-MO-OX CATALYST FOR OXIDATIVE AMONOLYSIS OF ISOBUTYL ALCOHOL
}

\author{
Lviv Polytechnic National University \\ 12 Bandera str., 79013 Lviv, Ukraine
}

Received: March 02, 2012 / Revised: J une 15, 2012 / Accepted: September 27, 2012

( Zhyznevskiy V., Gumenetskiy V., Matskiv O., Shyshchak O., 2013

\begin{abstract}
The effect of barium salts (nitrate, sulphate, chloride) on the physico-chemical and catalytic properties of Fe:Te:Mo (1:0.85:1) oxide catalyst has been determined for oxidative amonolysis of isobutyl alcohol (IBA) to methacrylonitrile (MAN). The catalyst doped with $\mathrm{BaCl}_{2}(\mathrm{Ba} / \mathrm{Mo}=0.1)$ was found to be the best catalyst relatively to the MAN yield. It has been shown that the promotors increase the catalyst specific surface and affect catalyst surface acidity improving the catalyst efficiency.
\end{abstract}

Keywords: catalysis, methacrylonitrile, catalyst, promotor.

\section{Introduction}

Isobutyl alcohol (IBA) is a by-product formed during the ethyl alcohol obtained via digestion of starch or sugar raw materials. IBA, as well as other alcohols, is a part of fusel oil (FO), the composition of which depends upon the initial material quantity and technological process peculiarities. Thus the content of different alcohols varies (mas \%): ethanol 5-7; $n$-propanol 7-15; IBA 10-20; isoamyl alcohol 50-60; water 5-10. Taking into account the productive capacity of distilleries, IBA may be used for production of different important chemical products.

In the present work we suggest to use IBA for obtaining methacrylates which may be used in different branches of industry. Taking into consideration that isobutylene oxidation or oxidative amonolysis (today it is used for the production of branched hydrocarbons gasoline high-octane components) are the main methods of methacrylates synthesis, a deficit of IB is observed. To our mind, IBA may be a raw material for methacrylates synthesis, namely for MAN production via IBA oxidative amonolysis. IBA converts into isobutylene at high temperatures over acid catalyst and then - into methacrolein (MA) in the presence of oxygen. MA, in its turn, also converts into MAN. Then methylmethacrylate (MMA) is obtained in the presence of $\mathrm{H}_{2} \mathrm{SO}_{4}$ and methanol. MMA, as well as MAN, are important monomers widely used in industry.

The simplified scheme of IBA conversion into MAN and MMA is:

$$
\begin{gathered}
\mathrm{IBA}+\mathrm{NH}_{3}+\mathrm{O}_{2} \stackrel{\mathrm{Cat}}{\longrightarrow} \mathrm{MAN}+\left(\mathrm{H}_{2} \mathrm{SO}_{4}+\mathrm{CH}_{3} \mathrm{OH}\right) \\
\text { MMA }\left(-\mathrm{NH}_{4} \mathrm{HSO}_{4}\right)
\end{gathered}
$$

It is well-known that oxide contact Fe:Te:Mo $(1: 0.85: 1)$ is the effective catalyst for olefins oxidation, isobutylene (IB) namely [1]. In work [2] authors investigated its doping with alkaline and alkaline-earth metals in the reaction of IB oxidative amonolysis to MAN. The best results relative to the MAN yield were obtained using alkaline-earth metals. The alkaline metals block partial oxidation centers and decrease the catalyst activity. The contact doped with barium nitrate $(\mathrm{Ba} / \mathrm{Mo}=$ $=0.1$ ) was found to be the best catalyst relative to the MAN yield. Over this catalyst the maximum yield of MAN $(91.5 \%)$ was obtained at $T=643 \mathrm{~K}, \tau_{c}=0.42 \mathrm{~s}$ and the composition of initial reaction mixture (mol \%): IB $2 ; \mathrm{NH}_{3}-3$ in the air [2]. Therefore we used oxide contact Fe:Te:Mo (1:0.85:1) for our investigations in the present work. Barium was a promoter. Such barium salts as sulfate or chloride are more stable and give better results in the processes of oxidative conversion compared with barium nitrate which decomposes to oxide during thermal treatment [3].

Thus, the aim of this work is to investigate the effect of barium salts (nitrate, sulfate, chloride) on the catalytic properties of $\mathrm{Fe}: \mathrm{Te}: \mathrm{Mo}: \mathrm{O}_{\mathrm{x}}$ catalyst in the reaction of IBA oxidative amonolysis. 


\section{Experimental}

The procedures of catalyst preparation, experiments and analysis of the reaction products are given in our previous work [4]. The experiments were carried out at $T=673 \mathrm{~K}, \tau_{c}=2.4 \mathrm{~s}$ in the continuous plant with impulse feed of the following mixture (mol \%): IBA - 4; $\mathrm{NH}_{3}-6$ in the air $\left(V_{\text {imp }}=12.5 \mathrm{~cm}^{3} ; V_{\text {flow }}=0.56 \mathrm{~cm}^{3} / \mathrm{s}\right)$.

The size of the catalyst specific surface was determined using the chromatographic method of argon thermal desorption [5].

The catalyst surface acidity was determined using the pulse chromatographic method of $\mathrm{NH}_{3}$ chemosorption over the catalyst surface. The catalyst sample corresponding to the total surface of the catalyst $\left(5 \mathrm{~m}^{2}\right)$ was loaded to the adsorber. Then the adsorber with the catalyst was involved in the chromatograph gas scheme following a doser and placed into a chromatograph thermostat. It was heated to $673 \mathrm{~K}$ and blown by helium for $1 \mathrm{~h}$ to release the surface from adsorbed gases. After this the temperature was reduced to $343 \mathrm{~K}$. $\mathrm{NH}_{3}$ impulses (dose of $1 \mathrm{~cm}^{3}$ ) were fed till the catalyst surface was saturated by the adsorbate. The control was carried out by the peak area at the output of thermal-conductivity detector. The amount of $\mathrm{NH}_{3}$ absorbed by the catalyst surface (the difference between supplied and nonabsorbed amount of $\mathrm{NH}_{3}$ ) was determined by the amount of supplied $\mathrm{NH}_{3}$ impulses and total area of non-absorbed $\mathrm{NH}_{3}$ chromatographic peaks in accordance with a calibration sensibility factor of detector under the experimental conditions. After the saturation of $\mathrm{NH}_{3}$ surface the adsorber was blown by helium for $30 \mathrm{~min}$ at the adsorption temperature and then the $\mathrm{NH}_{3}$ programmed thermodesorption was carried out. Two thermodesorption peaks were observed and they were used to calculate the thermodesorption activation energy considering a thermodesorption rate [5].

\section{Results and Discussion}

The obtained results at different $\mathrm{Ba} / \mathrm{Mo}$ ratio are represented in Table 1.

One can see that the ratio $\mathrm{Ba} / \mathrm{Mo}=0.1$ is the optimum one relatively to the MAN yield in all experiments. For the catalysts doped with $\mathrm{Ba}\left(\mathrm{NO}_{3}\right)_{2}$ and $\mathrm{BaSO}_{4}$ the MAN yield is $60 \%$ and for $\mathrm{BaCl}_{2}-70 \%$.

The increase in contact time to $3.6 \mathrm{~s}$ increases the MAN yield to $72 \%$ over the catalyst doped with $\mathrm{BaCl}_{2}$. The total MA+MAN yield under the mentioned conditions is $92 \%$ and since IBA conversion is $100 \%$, $20 \%$ of MA is formed. In the reaction of MA oxidative amonolysis to MAN over doped $\mathrm{BaCl}_{2}$ the selectivity is $95 \%$ (Table 4). Thus at the recirculation of $20 \%$ of MA the MAN total yield is $72+20 \cdot 0.95=91 \%$.

The interaction between MAN and $\mathrm{H}_{2} \mathrm{SO}_{4}$ results in the formation of methacrylic acid (MAA) and ammonium hydrosulphate:

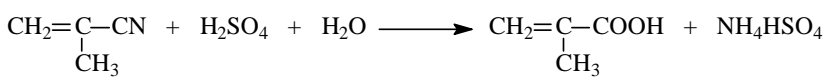

MMA is formed from MAN in the presence of $\mathrm{CH}_{3} \mathrm{OH}$ and $\mathrm{H}_{2} \mathrm{SO}_{4}$ as a catalyst

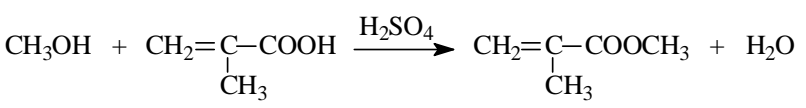

The MMA yield relatively to MAN is $90 \%$ [6]. Then the MMA yield relatively to IBA is $91 \cdot 0.9=81.9 \%$.

At isobutylene oxidative amonolysis over $\mathrm{Fe}-\mathrm{Te}$ Mo- $\mathrm{O}_{\mathrm{x}}$ doped with $\mathrm{Ba}\left(\mathrm{NO}_{3}\right)_{2}(\mathrm{Ba} / \mathrm{Mo}=0.1)$ [2] the MAN yield is $91.5 \%$, then the MMA yield is $91.5 \cdot 0.9=82.4 \%$. Using IBA the yield is $81.9 \%$, i.e. it is less by $0.5 \%$. Thus, IBA may be used as a raw material for MMA production.

Table 1

Physico-chemical and catalytic properties of Fe-Te-Mo-O catalysts doped with barium salts (reaction conditions see above)

\begin{tabular}{|c|c|c|c|c|c|c|c|c|c|c|c|c|c|c|c|c|c|c|}
\hline \multirow{2}{*}{$\begin{array}{c}\mathrm{Ba} / \mathrm{Mo} \text {, } \\
\text { atom. }\end{array}$} & \multicolumn{6}{|c|}{ Promoter $\mathrm{Ba}\left(\mathrm{NO}_{3}\right)_{2}$} & \multicolumn{6}{|c|}{ Promoter $\mathrm{BaSO}_{4}$} & \multicolumn{6}{|c|}{ Promoter $\mathrm{BaCl}_{2}$} \\
\hline & $S_{s}$ & $K \cdot 10^{3}$ & $E_{1} \pm 5$ & $E_{2} \pm 5$ & $X, \%$ & $Y$ & $S_{s}$ & $K \cdot 10^{3}$ & $E_{1} \pm 5$ & $E_{2} \pm 5$ & $X, \%$ & $Y$ & $S_{s}$ & $K \cdot 10^{3}$ & $E_{1} \pm 5$ & $E_{2} \pm 5$ & $X, \%$ & $Y$ \\
\hline 0 & 0.8 & 0.15 & 40 & 72 & 90 & 47 & & & & & & & & & & & & \\
\hline 0.05 & 0.9 & 0.2 & 35 & 68 & 82 & 56 & 0.6 & 2.0 & 30 & 65 & 89 & 53 & 0.9 & 0.7 & 18 & 54 & 95 & 53 \\
\hline 0.1 & 1.3 & 0.3 & 32 & 60 & 86 & 60 & 0.6 & 2.8 & 27 & 64 & 87 & 60 & 1.75 & 0.9 & 16 & 50 & 98 & 70 \\
\hline 0.2 & 1.2 & 0.17 & 25 & 42 & 84 & 57 & 0.7 & 2.4 & 25 & 68 & 88 & 38 & 2.5 & 0.8 & 14 & 30 & 96 & 47 \\
\hline 0.5 & 1.1 & 0.15 & 15 & 39 & 80 & 54 & 1.4 & 2.1 & 17 & 86 & 79 & 40 & 2.6 & 0.8 & 12 & 18 & 87 & 46 \\
\hline
\end{tabular}

Notes: $S_{s}$ - catalyst specific surface after activation, $\mathrm{m}^{2} / \mathrm{g} ; K-$ surface acidity, $\mathrm{mmol} / \mathrm{m}^{2} ; E_{1}$ and $E_{2}-$ activation energies of $\mathrm{NH}_{3}$ thermosorption from the catalyst surface determined by desorption rate, $\mathrm{kJ} / \mathrm{mol} ; X-\mathrm{IB}$ conversion, \% (IBA conversion is $100 \%) ; Y$ - MAN yield, $\%\left(Y=X \cdot S_{s}\right)$ 
Nitrates of alkaline-earth elements are used as promoters in [2]. They decompose to the oxides during a catalyst thermal treatment. In some works [3] it was shown that anion of salt, which is stable under the reaction conditions, also influences the catalytic properties. For example, the efficiency of barium salts relatively to the MAN yield (Table 1) may be represented in a row: $(\mathrm{Ba} / \mathrm{Mo}=0.1): \mathrm{BaCl}_{2}>\mathrm{BaSO}_{4}=\mathrm{Ba}\left(\mathrm{NO}_{3}\right)_{2}$.

The effect of barium salt concentration on the physico-chemical and catalytic properties of investigated catalysts is given in Table 1 . The specific surface $\left(S_{s}\right)$ of the catalysts doped with $\mathrm{Ba}\left(\mathrm{NO}_{3}\right)_{2}$ and $\mathrm{BaCl}_{2}$ is greater than that of the initial one. The surface of the catalyst doped with $\mathrm{BaSO}_{4}$ is greater only at higher concentration of the dopant, namely $\mathrm{Ba} / \mathrm{Mo}=0.5$.

Since the oxidative amonolysis takes place over the contact surface [9] during the heterogeneous catalysis, the increase of $S_{s}$ has to increase the catalyst activity. On the contrary the maximum IB conversion of $90 \%$ is observed over undoped catalyst (IBA conversion is $100 \%$ in all experiments). However IB conversion decreases with the increase of $\mathrm{Ba}\left(\mathrm{NO}_{3}\right)_{2}$ and $\mathrm{BaSO}_{4}$ concentration. For the catalyst doped with $\mathrm{BaCl}_{2}$ the conversion increases to $96 \%$ compared with undoped catalyst at the ratio $\mathrm{Ba} / \mathrm{Mo}=0.2$ and decreases to $87 \%$ for the catalyst with the ratio $\mathrm{Ba} / \mathrm{Mo}=0.5$. To our mind this fact may be explained by the blocking of the surface strong acid centers by the dopant, i.e. the increase of promoter concentration increases the specific surface and has to increase the conversion, but at the same time the blocking extent increases resulting in the rate deceleration and as a consequence, in the conversion reduction. Using $\mathrm{BaCl}_{2}$ we observe the triple effect: the increase of specific surface and blocking extent, and the presence of $\mathrm{Cl}^{-}$. The latter one weakens $\mathrm{C}-\mathrm{H}$ bond and in such a way favors the increase of hydrogen detachment rate at the first stage of the process $-\pi$-allyl radical formation:

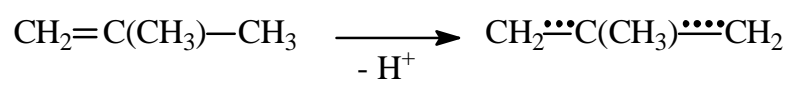

The parameters of determined surface acidity are given in Table 1. This value is maximum for the optimum catalysts relatively to the MAN yield $(\mathrm{Ba} / \mathrm{Mo}=0.1)$. Obviously the cation $\mathrm{Ba}^{2+}$ of the barium salt plays the main role for the catalyst acidity and promotion mechanism. The catalyst doped with $\mathrm{BaCl}_{2}$ has the maximum surface acidity $\left(K_{x}\right)$. At the same time this catalyst is the best relatively to MAN yield. The higher selectivity of the catalysts doped with $\mathrm{BaCl}_{2}$ compared with other dopants was discussed above.

The analysis of the acid centers strength concerning the activation energy of $\mathrm{NH}_{3}$ thermodesorption shows that dopants considerably decrease the strength of acid centers of both the first and the second peaks for all promoters.
Moreover the strength of acid centers $\left(E_{d e s}\right)$ decreases with the increase of dopant concentration.

The analysis of desorption products shows that MAN was absent in the first peak of desorption. Probably IB and MA are insufficiently active over these centers. The second desorption form is the determinant for MAN production. Moreover, the catalyst doped with $\mathrm{BaCl}_{2}$ $(\mathrm{Ba} / \mathrm{Mo}=0.1)$ has the minimum desorption activation energy and the greatest MAN yield $(72 \%)$ at $673 \mathrm{~K}$ and contact time of $3.6 \mathrm{~s}$.

We also investigated IBA adsorption and desorption over Fe-Te-Mo- $\mathrm{O}_{\mathrm{x}}$ catalyst doped with $\mathrm{BaCl}_{2}$. The same two thermosorption peaks were observed, i.e. two kinds of alcohol adsorption exist. The first one is the centers of weak adsorption $\left(T_{\max }=368-395 \mathrm{~K} ; E_{\text {des }}=22\right.$ $40 \mathrm{~kJ} / \mathrm{mol}$ ) and products which are thermally desorbed over them are: IBA, IB, MA, $\mathrm{CO}$ and $\mathrm{CO}_{2}$. Over the second kind of centers the thermodesorption takes place at higher temperatures $(620-693 \mathrm{~K})$ and desorption activation energy of $50-75 \mathrm{~kJ} / \mathrm{mol}$. The products are: IB, MA, MAN, $\mathrm{CO}$ and $\mathrm{CO}_{2}$. The minimum $T_{\max }$ of the first peak has the catalyst with ratio $\mathrm{Ba} / \mathrm{Mo}=0.05-0.01$ and the minimum $E_{d e s}=22 \mathrm{~kJ} / \mathrm{mol}$ has the undoped catalyst. The maximum $E_{\text {des }}=40 \mathrm{~kJ} / \mathrm{mol}$ has the catalyst with ratio $\mathrm{Ba} / \mathrm{Mo}=0.1$ which is the best relatively to the MAN yield. In the case of second desorption peak the best catalyst has minimum $T_{\max }=623 \mathrm{~K}$ and low $E_{\text {des }}=57 \mathrm{~kJ} / \mathrm{mol}$. The minimum $E_{\text {des }}$ is observed over the catalyst with the dopant maximum concentration and ratio $\mathrm{Ba} / \mathrm{Mo}=0.5$.

Obviously that at high concentration of dopants both centers of complete and partial oxidation are blocked accompanied by the decrease of catalyst activity and the MAN yield (Table 1). The undoped catalyst has the maximum $E_{d e s}$. Thus, the catalyst which is an optimal one relatively to the MAN yield, should have a small amount of dopant and moderate $E_{d e s}=55-57 \mathrm{~kJ} / \mathrm{mol}$. The surface acidity should also have the moderate value. We assume that centers of the first type are Lewis ones and stronger centers are Brønsted ones.

One can see from Tables 1 and 2 that the maximum amount of IBA is absorbed over the catalyst doped with $\mathrm{BaCl}_{2}(\mathrm{Ba} / \mathrm{Mo}=0.1)$ which is the optimal one relatively to the MAN yield. This amount of surface covering degree is approximately 1 (Table 2) and amount of $\mathrm{NH}_{3}$ adsorption centers is maximum as well (adsorption proceeds till $\mathrm{NH}_{3}$ saturates the catalyst surface). Since the IBA oxidative amonolysis proceeds via redox mechanism, the MAN formation takes place without oxygen, i.e. via interaction between IB (dehydration product of IBA) and oxygen adsorbed on the surface or oxygen of the catalyst lattice. As it was shown in [1], at olefin concentration $>3 \mathrm{~mol} \%$, the rate of MA formation depends only on oxygen concentration, i.e. the interaction between IB and 
oxygen is a limiting stage. Therefore it was advisable to investigate the effect of the reactivation degree of the optimum catalyst $\mathrm{Ba} / \mathrm{Mo}=0.1\left(\mathrm{BaCl}_{2}\right)$. Obviously, the reactivation degree of the catalyst surface depends upon the ratio reducing agent: oxygen, concentration of alkaline-earth promoter affecting the mobility of the surface oxygen and the catalyst activity and selectivity.

The experiments were carried out in the flow reactor with a pulsed feed of the initial mixture containing $5 \mathrm{~mol} \%$ of IBA in helium; $T=673 \mathrm{~K} ; V_{i m p}=5.5 \mathrm{~cm}^{3}$; $V_{\text {flow }}=0.56 \mathrm{~cm}^{3} / \mathrm{s}$; catalyst total surface $\Sigma S_{\text {cat }}=2.6 \mathrm{~m}^{2}$; catalyst mass $m_{\text {cat }}=3 \mathrm{~g} ; \tau_{c}=3.6 \mathrm{~s}$ (Table 3 ).

Under the experimental conditions IBA converts completely, thus the calculations were carried out for IB which was present at the reactor outlet. For the first 5 impulses of the initial mixture the products were analyzed in every impulses, then every $5^{\text {th }}$ impulse (till 30) and every $10^{\text {th }}$ impulse till the end of the experiment. The catalyst reactivation degree was determined taking into account the amount of formed oxidation products. The obtained results (Table 3) allow to conclude:

- at the recovery of $70 \%$ of oxygen monolayer in the first impulse (oxygen monolayer is $0.2 \mathrm{~cm}^{3} / \mathrm{m}^{2}$ [7]) the IB conversion decreases by $10 \%$ and selectivity relatively to MA increases by $17 \%$ in the following impulse;

- in the next 4 impulses (including the $5^{\text {th }}$ one) more than 3 oxygen monolayers are recovered from the surface.
At the same time IB conversion is constant, selectivity relatively to MAN increases from 67.5 to $91.7 \%$ and selectivity relatively to $\mathrm{CO}+\mathrm{CO}_{2}$ decreases from 49.4 to $8.3 \%$. Hence, there are great amounts of active oxygen on the surface of non-activated catalyst; oxygen converts IBA and IB into the products of complete oxidation. After oxygen recovering (the $5^{\text {th }}$ impulse) to the $25^{\text {th }}$ impulse the yield of the complete oxidation products is constant but IB conversion decreases from 87.6 (the $5^{\text {th }}$ impulse) to $9 \%$ (the $45^{\text {th }}$ impulse). The rate of IB oxidation decreases as well from $1.29 \cdot 10^{-6}$ to $0.15 \cdot 10^{-6} \mathrm{~mol} / \mathrm{m}^{2} \cdot \mathrm{s}$.

- during the following feed of the initial mixture from the $5^{\text {th }}$ to the $45^{\text {th }}$ impulse the IB conversion decreases from 87.6 to $9 \%$. The oxidation rate decreases from $1.19 \cdot 10^{-6}$ to $0.15 \cdot 10^{-6} \mathrm{~mol} / \mathrm{m}^{2} \cdot \mathrm{s}$.

As it was shown in [1] the catalyst reactivation degree depends on IB concentration in the reaction mixture which is determined in our case by IBA concentration and the rate of its dehydration to IB under the process conditions. According to [1], the optimum catalyst relatively to the MAN yield is the catalyst over which the rate of MA conversion into MAN exceeds the rate of IB formation (Table 4). The catalyst phase composition is formed at IB concentration of 2-7 mol \%. Thus the catalyst must work at the presence of the mentioned range of IB concentration.

Table 2

IBA adsorption and thermodesorption over Fe-Te-Mo-O catalysts doped with $\mathrm{BaCl}_{2}$ $\left(T_{a d s}=343 \mathrm{~K}\right.$; thermodesorption was carried out at the temperature programming $\left.16^{\circ} / \mathrm{min}\right)$

\begin{tabular}{|c|c|c|c|c|c|c|c|}
\hline \multirow{3}{*}{$\begin{array}{c}\mathrm{Ba} / \mathrm{Mo} \text {, } \\
\text { atom. }\end{array}$} & \multirow{3}{*}{$\begin{array}{c}\text { Volume of adsorbed } \\
\text { IBA }\left(V \cdot 10^{3}\right), \\
\mathrm{mmol} / \mathrm{m}^{2}\end{array}$} & \multirow{3}{*}{$\begin{array}{c}\text { IBA adsorption } \\
\text { centers }\left(N_{c} \cdot 10^{18}\right), \\
\text { centers } / \mathrm{m}\end{array}$} & \multirow{3}{*}{$\begin{array}{c}\text { Degree of surface } \\
\text { covering by IBA }(\theta) \text {, } \\
\% \text { of monolayer }\end{array}$} & \multicolumn{4}{|c|}{ Thermodesorption } \\
\hline & & & & \multicolumn{2}{|c|}{ First peak } & \multicolumn{2}{|c|}{ Second peak } \\
\hline & & & & $\begin{array}{c}T_{\max } \\
\mathrm{K}\end{array}$ & $\begin{array}{c}E_{\text {des }}, \\
\mathrm{kJ} / \mathrm{mol}\end{array}$ & $\begin{array}{c}T_{\max }, \\
\mathrm{K}\end{array}$ & $\begin{array}{c}E_{d e s}, \\
\mathrm{~kJ} / \mathrm{mo}\end{array}$ \\
\hline 0 & 3.8 & 2.3 & 0.72 & 375 & 22 & 660 & 75 \\
\hline 0.05 & 3.5 & 2.3 & 0.95 & 368 & 29 & 693 & 83 \\
\hline 0.10 & 5.4 & 3.3 & 1.05 & 368 & 40 & 623 & 83 \\
\hline 0.20 & 3.0 & 1.8 & 0.57 & 386 & 27 & 640 & 55 \\
\hline 0.50 & 2.8 & 1.7 & 0.54 & 395 & 26 & 657 & 50 \\
\hline
\end{tabular}

Table 3

Reactivation of $\mathrm{FeTe}_{0.85} \mathrm{MoBa}_{0.1} \mathrm{O}_{\mathrm{x}}$ catalyst by the impulses of the initial mixture (IM)

\begin{tabular}{|c|c|c|c|c|c|c|}
\hline $\begin{array}{c}\text { Impulse } \\
\text { number }\end{array}$ & $X_{I B}, \%$ & $S_{M A}, \%$ & $S_{\mathrm{CO}}, \%$ & $S_{\mathrm{CO} 2}, \%$ & $\begin{array}{c}W_{I B} \cdot 10^{6}, \\
\mathrm{~mol} /\left(\mathrm{m}^{2} \cdot \mathrm{s}\right)\end{array}$ & $\begin{array}{c}\text { Reactivation degree, } \\
\% \text { of monolayer }\end{array}$ \\
\hline 1 & 97.2 & 50.5 & 40.8 & 8.6 & 1.29 & 70.0 \\
\hline 2 & 88.7 & 67.5 & 23.6 & 8.9 & 1.20 & 150.0 \\
\hline 3 & 88.7 & 76.5 & 16.5 & 7.1 & 1.18 & 214.0 \\
\hline 4 & 87.2 & 88.2 & 5.8 & 6.0 & 1.21 & 289.0 \\
\hline 5 & 87.6 & 91.7 & 2.0 & 6.3 & 1.19 & 362.0 \\
\hline 15 & 74.3 & 91.0 & 2.4 & 6.6 & 0.87 & 619.0 \\
\hline 25 & 33.9 & 85.4 & 4.3 & 10.3 & 0.52 & 745.0 \\
\hline 45 & 9.0 & 85.0 & 5.2 & 8.8 & 0.15 & 925.0 \\
\hline
\end{tabular}


Table 4

\section{IB oxidation to MA and oxidative amonolysis of IB, MA and IBA to MAN over Fe-Te-Mo- $\mathrm{O}_{\mathrm{x}}$ catalyst doped with $\mathrm{BaCl}_{2}(\mathrm{Ba} / \mathrm{Mo}=\mathbf{0 . 1})$ in the impulse reactor at $613 \mathrm{~K} ; \tau_{c}=1.2 \mathrm{~s} ; V_{i m p}=12.5 \mathrm{~cm}^{3}$. The reaction mixture (mol \%): $\mathrm{RH}-4 ; \mathrm{NH}_{3}-6$ in the air}

\begin{tabular}{|c|c|c|c|c|c|c|c|}
\hline \multirow{2}{*}{ No. } & \multirow{2}{*}{ Mixture composition } & \multirow{2}{*}{$X_{I B}, \%$} & \multirow{2}{*}{$S_{M A N}, \%$} & \multirow{2}{*}{$S_{M A}, \%$} & \multicolumn{3}{|c|}{$W, \mathrm{~mol} / \mathrm{dm}^{2} \cdot \mathrm{s}$} \\
\hline & & & & & MA & MAN & IB \\
\hline 1 & $\mathrm{IB}+\mathrm{O}_{2}$ & 73.0 & - & 86.0 & 13.0 & - & 14.0 \\
\hline 2 & $\mathrm{IB}+\mathrm{O}_{2}+\mathrm{NH}_{3}$ & 65.0 & 70.0 & 20.0 & 3.0 & 8.5 & 11.5 \\
\hline 3 & $\mathrm{MA}+\mathrm{O}_{2}+\mathrm{NH}_{3}$ & $78.0 *$ & 95.0 & - & 16.0 & 12.0 & - \\
\hline 4 & $\mathrm{IBA}+\mathrm{O}_{2}+\mathrm{NH}_{3}$ & 75.0 & 30.0 & 45.0 & 4.8 & 7.2 & 12.0 \\
\hline
\end{tabular}

Notes: for the mixture No. 3: $W_{M A}$ - rate of MA consumption; for the mixture No. 4: $X_{I B A}=100 \%$; $\mathrm{RH}-\mathrm{IB}, \mathrm{MA}, \mathrm{IBA} ; *$ - MA conversion.

After the feed of the $45^{\text {th }}$ impulse of the initial mixture the impulses of oxidative mixture $(\mathrm{OM})$ with oxygen concentration of $10 \mathrm{~mol} \%$ and the amount of strongly chemosorbed products on the catalyst surface was determined in accordance with the formed $\mathrm{CO}_{2}$ to calculate for IB. $\mathrm{CO}_{2}$ is formed over the time of 4 impulses of $\mathrm{OM}$. The amount of fed oxygen is $5.5 \cdot 4 \cdot 0.1=2.23 \mathrm{~cm}^{3}$. Taking into account the catalyst mass of $3 \mathrm{~g}$ and total surface of $2.6 \mathrm{~m}^{2}, 0.189 \mathrm{~cm}^{3}$ of $\mathrm{CO}_{2}$ was removed; to calculate for IB $-0.047 \mathrm{~cm}^{3}$ or $19 \%$ of monolayer's covering (IB monolayer $0.096 \mathrm{~cm}^{3}[8]$ ) calculated for $1 \mathrm{~m}^{2}$ of the catalyst surface: $0.047 / 0.096 \cdot 2.6 \cdot 100 \%=19 \%$.

The reactivation of the optimum catalyst relatively to the MAN yield doped with $\mathrm{BaCl}_{2}(\mathrm{Ba} / \mathrm{Mo}=0.1)$ by the mixture IBA $+\mathrm{NH}_{3}$ has been investigated as well (Fig. 1). The experimental conditions are given above (Table 3 ).

The IB oxidation rate increases to the $5^{\text {th }}$ impulse and the selectivity relatively to MAN decreases (Fig. 1). After the feed of impulses from the $5^{\text {th }}$ to the $50^{\text {th }}$ the rate decreases from $13.8 \cdot 10^{-7}$ (maximum one) to $2.6 \cdot 10^{-7} \mathrm{~mol} / \mathrm{m}^{2} \cdot \mathrm{s}$ but the selectivity increases from 75 to $96 \%$ with 14 monolayers removing.

The comparison of catalyst reactivation by pure IBA (Table 3) and IBA+NH $\mathrm{NH}_{3}$ (Fig. 1) shows that $\mathrm{NH}_{3}$ in the initial mixture retards the rate of IB conversion $w$ (IBA conversion is $100 \%$ in all experiments). Thus in the $1^{\text {st }}$ impulse without $\mathrm{NH}_{3}$ (Table 3) $w=12.9 \cdot 10^{-7} \mathrm{~mol} / \mathrm{m}^{2} \cdot \mathrm{s}$, in the presence of $\mathrm{NH}_{3}$ it is $8.0 \cdot 10^{-7} \mathrm{~mol} / \mathrm{m}^{2} \cdot \mathrm{s}$ (Fig. 1) and increases till the $5^{\text {th }}$ impulse. After achieving the maximum value of $13.8 \cdot 10^{-7} \mathrm{~mol} / \mathrm{m}^{2} \cdot \mathrm{s}$ the rate decreases to $2.6 \cdot 10^{-7} \mathrm{~mol} / \mathrm{m}^{2} \cdot \mathrm{s}$ (the $50^{\text {th }}$ impulse). However this rate is higher than that at the catalyst reactivation by pure alcohol $\left(1.5 \cdot 10^{-7} \mathrm{~mol} / \mathrm{m}^{2} \cdot \mathrm{s}\right.$ in the $45^{\text {th }}$ impulse $)$.

To our mind all these facts may be explained by the following. When the catalyst is reactivated by pure IBA the end-product of partial oxidation is MA; when $\mathrm{IBA}+\mathrm{NH}_{3}$ is used, MAN is the end-product. Therefore in the second case the total rate of alcohol conversion $w_{a l}=w_{M A}+w_{M A N}$. The increase of IBA conversion rate in the first impulses is explained by the fact that the catalyst surface has strong acid centers over which $\mathrm{NH}_{3}$ converts into $\mathrm{N}_{2}$. Hence, with the increase of impulses amount the centers are blocked by $\mathrm{NH}_{3}$, that retards $\mathrm{N}_{2}$ formation and increases the rate of MAN formation. Moreover, in the reaction of MAN formation $\mathrm{NH}_{3}$ reacts with oxygen of the catalyst surface and forms $=\mathrm{NH}$ particle which further reacts with adsorbed MA and forms MAN.

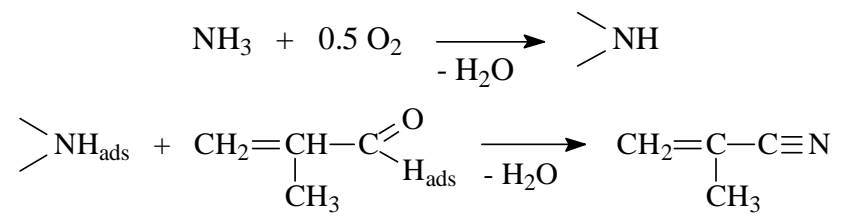

The results presented in Table 4 confirm the MA conversion into MAN. According to the Table data the rate of this conversion is higher than that of IB conversion into MAN. The selectivity relatively to MAN is higher as well $\left(X_{I B}=65 \%, S^{I B}{ }_{M A N}=70 \%, X_{M A}=78 \%, S^{M A}{ }_{M A N}=\right.$ $=95 \%)$. The conversion of $\mathrm{IB}+\mathrm{O}_{2}+\mathrm{NH}_{3}$ is $65 \%$, less than IB conversion into MAN (73\%). Thus, the presence of $\mathrm{NH}_{3}$ in the mixture retards IB oxidation into MAN because it blocks not only strong acid centers but the centers of partial oxidation as well. Since the rate of MA conversion into MAN is considerably higher than that of IB into MAN and higher than the rate of IB into MA, we may assume that the formation of intermediate product MA - is the limiting stage of IB oxidative amonolysis into MAN. While studying the process kinetics we established that the MAN formation from both IB and MA proceeds via redox mechanism and retards by $\mathrm{NH}_{3}$; at the same time strong acid centers of complete oxidation products are blocked first of all. $\mathrm{CO}_{2}$ is formed only at low $\mathrm{NH}_{3}$ concentrations. At the $\mathrm{NH}_{3}$ excess only MAN is formed.

The results of undoped $\mathrm{Fe}-\mathrm{Te}_{0.85}-\mathrm{Mo}-\mathrm{O}_{\mathrm{x}}$ catalyst reactivation by $\mathrm{IBA}+\mathrm{NH}_{3}$ mixture are presented in Fig. 2 . The maximum oxidation rate for doped catalyst is 13.8 . $\cdot 10^{-7} \mathrm{~mol} / \mathrm{m}^{2} \cdot \mathrm{s}$ and only $8.5 \cdot 10^{-7} \mathrm{~mol} / \mathrm{m}^{2} \cdot \mathrm{s}-$ for undoped 
one. For 20 impulses of the initial mixture 10 monolayers are removed from the doped catalyst and 5 ones - from undoped catalyst. After 20 impulses the selectivity relatively to MAN is $75 \%$ for doped catalyst and $20 \%-$ for undoped one. At the same time MAN is formed after the $20^{\text {th }}$ impulse using undoped catalyst and after the first one - using the doped catalyst. Over the undoped catalyst $\mathrm{NH}_{3}$ converts into $\mathrm{N}_{2}$ after the $10^{\text {th }}$ impulse.

Thus, the dopant considerably improves the catalytic properties of $\mathrm{Fe}-\mathrm{Te}-\mathrm{Mo}-\mathrm{O}_{\mathrm{x}}$ catalyst increasing its activity and selectivity relatively to MAN.

The additional oxygen consumption at the process first stage is also confirmed by the fact that during catalyst reactivation by pure IBA 9.25 monolayers of oxygen are removed for 45 impulses and in the presence of $\mathrm{NH}_{3}-$ 13.5 monolayers are removed for the same impulses (Table 3 and Fig. 1, correspondingly). The decrease of the catalyst selectivity relatively to MA (Table 3 ) from the $15^{\text {th }}$ to the $45^{\text {th }}$ impulses may be explained by the phase composition change of the catalyst surface layer at high reactivation degree.

One can see from Fig. 1 that during the catalyst reactivation for 50 impulses 14 monolayers are removed and 9.5 monolayers are absorbed. Thus, surface reoxidation is slower than the catalyst reactivation. That is why during kinetics investigations of IB oxidation into MA we observe the first order by oxygen and zero order by olefin [1].

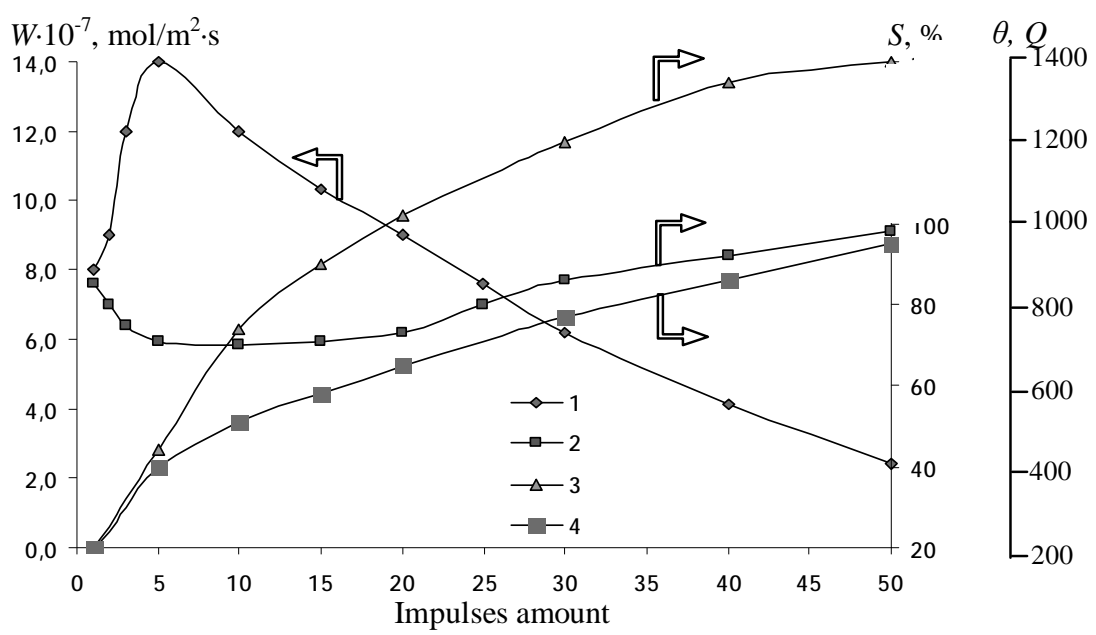

Fig. 1. Catalyst reactivation by $\mathrm{IBA}+\mathrm{NH}_{3}(1: 1 \mathrm{~mol})$ mixture and reoxidation by oxygen of the reactivated catalyst (doped with $\left.\mathrm{BaCl}_{2}(\mathrm{Ba} / \mathrm{Mo}=0.1)\right)$ before its activation: IB conversion rate (1) (IBA conversion is $100 \%$ in all cases); selectivity relatively to MAN (2); degree of oxygen removal by initial mixture impulses (3) and oxygen absorption by the catalyst while feeding reoxidation mixture (4)

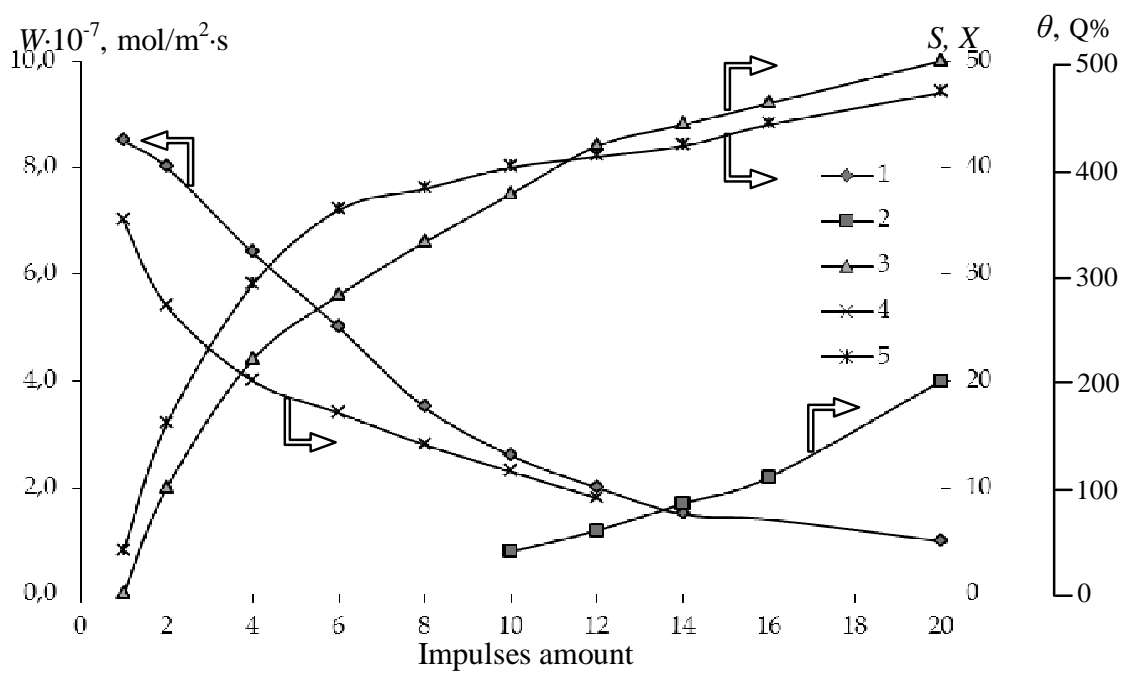

Fig. 2. Catalyst reactivation by $\mathrm{IBA}+\mathrm{NH}_{3}(1: 1 \mathrm{~mol})$ mixture and reoxidation by oxygen of the reactivated undoped catalyst: IB conversion rate (1) (IBA conversion is $100 \%$ in all cases); selectivity relatively to MAN (2); degree of oxygen removal by initial mixture impulses (3); oxygen absorption by the catalyst while feeding reoxidation mixture (4) and $\mathrm{NH}_{3}$ conversion (5) 
On the basis of obtained results and literature data we propose the following mechanism of IBA oxidative amonolysis:

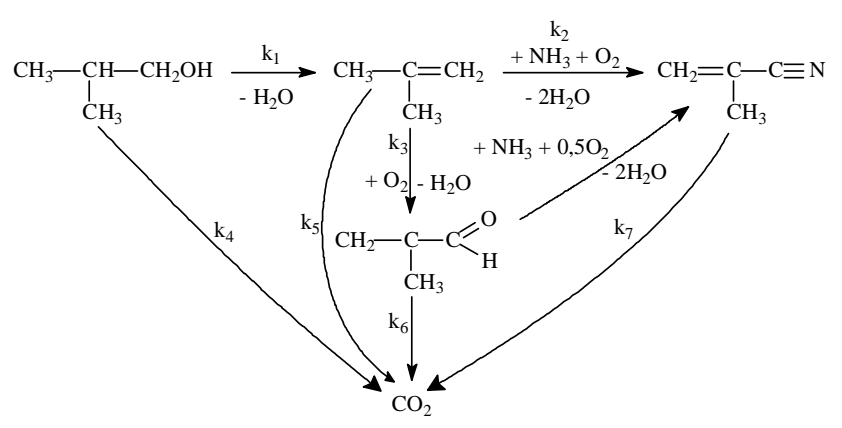

The process intermediate products are: IB obtained via IBA dehydration, and MA obtained via isobutylene oxidation. The reaction 1 takes place over the catalyst acid centers forming isobutylene which converts into metacrylonitrile by redox mechanism and into the intermediate product - metacrolein - which also converts into into metacrylonitrile by the same mechanism. The complete oxidation product $\mathrm{CO}_{2}$ is formed from IBA, IB, MA and MAN. The latter one is the most stable in the mentioned reaction.

All reactions proceeding by redox mechanism take place only in the presence of oxygen of the catalyst surface layer. The dopant introduced into the catalyst composition increases the oxygen mobility (Figs. 1 and 2, [2]). $\mathrm{CO}_{2}$ is formed between chemosorbate over the catalyst surface and oxygen of gaseous phase; it is so called "percussion mechanism". The dopants block the strong acid centers of the surface over which the complete oxidation products are formed. The same role is for $\mathrm{NH}_{3}$ in the mixture.

The acid centers of the catalyst surface take part in the activation of organic reagents and form the intermediate activated complex between catalyst active center and reagent, what weakens the chemical bonds participating in the reaction.

Obviously in the oxidation process the activation of the catalyst surface oxygen is necessary. It is assumed that activation proceed [2] over the surface main centers, then $\mathrm{Fe}-\mathrm{Te}-\mathrm{Mo}-\mathrm{O}_{\mathrm{x}}$ doped by alkaline-earth element should form additional main centers of oxygen activation and it will be as follows:

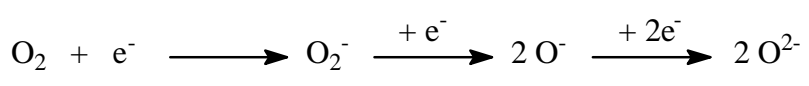

The oxygen activity depends upon the quantity of attached electrons. The oxygen high activity is undesirable in the reactions of hydrocarbons partial oxidation because it leads to the formation of complete oxidation products and decreases the process selectivity.
The strength of the catalyst acid canters should not be high because it leads to the formation of destruction products and decreases the selectivity.

\section{Conclusions}

The effect of barium salts (nitrate, sulphate, chloride) on the physico-chemical and catalytic properties of Fe:Te:Mo catalyst (1:0.85:1 atomic ratio) has been investigated in the reaction of oxidative amonolysis of isobutyl alcohol to methacrylonitrile. $\mathrm{BaCl}_{2}$ was found to be the best dopant $(\mathrm{Ba} / \mathrm{Mo}=0.1)$. The highest methacrylonitrile yield $(91 \%)$ is observed over the mentioned catalyst.

Isobutyl alcohol may be the raw material for methacrylates synthesis.

The optimum conditions of MAN production via oxidative amonolysis of isobutyl alcohol over $\mathrm{Fe}-\mathrm{Te}-\mathrm{Mo}$ oxide catalyst doped with $\mathrm{BaCl}_{2}$ are: temperature $673 \mathrm{~K}$ and contact time $3.6 \mathrm{~s}$.

\section{References}

[1] Zhyznevsky V.: Doctoral thesis. Moscow ChemicalTechnological Institute, Moskwa 1982.

[2] Zhyznevsky V., Roksana M., Kozharsky V and Kucher R.: Dop. Nats.Akad.Nauk URSR B, 1991, 3, 118.

[3] Zhyznevsky V., Gumenetskiy V., Bazhan L. and Maikova S.: Praci Nauk. Tovarystva im. Shevchenka, 2003, X, 103.

[4] Zhyznevsky V., Gumenetskiy V., Bazhan L. and Maikova S.: Zh. Phys. Khimii, 2001, 75, 1782.

[5] McClennon A. and Harnsberger H.: J. Coll. Interf. Sci., 1967, 23, 577.

[6] Chernykh S. (Ed.): Novye Processy Organicheskogo Sinteza. Khimiya, Moskwa 1989.

[7] Ai M.: Shokubai Catalyst, 1976, 18, 17.

[8] Ai M.: J. Catalysis, 1978, 52, 16.

[9] Kostynyk A. and Nikolenko M.: Chem. \& Chem. Techn., 2011, $\mathbf{5}, 89$.

\section{ВПЛИВ СОЛЕЙ БАРІЮ НА ФІЗИКО-ХІМІЧНІ ТА КАТАЛІТИЧНІ ВЛАСТИВОСТІ Fe-Те-Мо-О КАТАЛІЗАТОРА РЕАКЩІЇ ОКИСНЮВАЛЬНОГО АМОНОЛІЗУ ІЗОБУТИЛОВОГО СПИРТУ}

Анотація. Досліджено вилив солей барію (нітрат, сульфат, хлорид) на фізико-хімічні і каталітичні властивості Fe:Te:Mo (1:0,85:1) оксидного каталізатора реакиії окиснювального амонолізу ізобутилового спирту (ІБС) в метакрилонітрил (МАН). Встановлено, що кращим за виходом МАН є каталізатор (Km), промотований $\mathrm{BaCI}_{2}(\mathrm{Ba} / \mathrm{Mo}=0,1)$. Показано, щзо промотори збільшують питому поверхню $\left(S_{n}\right)$ Кт та впливають на його поверхневу кислотність, що покращує ефективність каталізатора в реакиії окиснювального амонолізу ІБС в МАН.

Ключові слова: каталіз, метакрилонітрил, каталізатор, промотор. 